Diana Poskuta-Włodek

\title{
Zmowa kobiet? Inscenizacje feministyczne w polskim teatrze dwudziestolecia międzywojennego
}

\begin{abstract}
Poskuta-Włodek Diana, Zmowa kobiet? Inscenizacje feministyczne w polskim teatrze $d w u d z i e s t o l e c i a ~ m i e ̨ d z y w o j e n n e g o$ [Collusion between women? Feminist stagings in Polish theater during the interwar period]. „Przestrzenie Teorii” 23. Poznań 2015, Adam Mickiewicz University Press, pp. 105-120. ISBN 978-83-232-2920-9. ISSN 1644-6763. DOI 10.14746/pt.2015.23.7.

The first wave of feminism in Poland consisted of a wide range of events. All women who were educated, independent, and professionally active and successful were regarded as feminists (regardless of their self-identification). Women of the theater, i.e., playwrights, directors, actresses and scenographers, who occupied themselves with "womanly subjects" in the 1920s and 1930s, created feminist theater which was important though it did not last long. In numerous feminist performances, theatrical productions dealt with subjects such as women in control of their own sexuality and bodies, women's full participation in life, as well as economic independence and equal rights for women. Feminists in Polish theater, for example, Zofia Modrzewska, Maria Morozowicz-Szczepkowska, Irena Grywińska and Marcelina Grabowska, were typically not treated seriously by male critics, who were condescending, scornful, and unable to transcend their male perspective.
\end{abstract}

„Są to panie z różnych obozów, ale myślą torem jednakowym” - pisał Karol Irzykowski w roku 1933 po przedstawieniu Zalotników niebieskich Marii Pawlikowskiej-Jasnorzewskiej w warszawskim Teatrze Małym ${ }^{1}$ o - jak to ujął - „bardzo ruchliwej grupie” polskich „przedstawicielek feminizmu" podejmujących w twórczości literackiej i publicystyce współczesną tematykę kobiecą. Oprócz autorki Zalotników zaliczył do tej kategorii pisarki o tak odmiennych poglądach i temperamentach, jak Maria Morozowicz-Szczepkowska i Irena Krzywicka2. Także sama Morozowicz-Szczepkowska, dostrzegając prawdziwą „erupcję talentów kobiecych w każdej dziedzinie twórczości”, wymieniała kobiety bardzo różne: zmarłą w 1928 roku młodopolską poetkę Bronisławę Ostrowską; absolwentkę Oksfordu, sekretarkę Piłsudskiego Kazimierę Iłłakowiczównę oraz apologetkę marszałka, pisarkę Marię Wielopolską; powieściopisarki „społeczne” - Nałkowską i Gojawiczyńską, „psychologizującą” - Kuncewiczową; komunizujące działaczki i publicystki: Halinę Krahelską - walczącą

${ }^{1}$ Prapremiera 14 XII 1933 roku, reżyseria Janusz Warnecki, dekoracje Stanisław Śliwiński.

2 K. Irzykowski, Pisma teatralne 1930-1933, t. 3, Kraków 1995, s. 642. 
o opiekę społeczną i prawo pracujących kobiet do godnego macierzyństwa, redaktorkę „Robotnika” Elżbietę Szemplińską, Wandę Wasilewską. Ponadto - reportażystkę i autorkę powieści społeczno-obyczajowych Wandę Melcer, redaktorkę „Bluszczu” Stefanię Okołów-Podhorską, Kazimierę Muszałównę - lotniczkę i autorkę rubryki „Świat się zmienia” w „Życiu Warszawy". Niewiele, delikatnie rzecz ujmując, wspólnych poglądów łączyło, również wymieniane przez Morozowicz-Szczepkowską, trzy Kossakówny: siostry Pawlikowską-Jasnorzewską i Magdalenę Samozwaniec z ich kuzynką - Zofią Kossak-Szczucką . A przecież można by do tej listy dodać wiele nazwisk, chociażby krakowsko-warszawską dziennikarkę Jadwigę Migową.

Różnorodność postaw, zainteresowań, poglądów i obszarów działalności kobiet oznaczanych wspólną etykietą dowodzi płynności pojęcia feminizmu w Polsce lat trzydziestych XX wieku. Do feministek zaliczano en bloc kobiety wykształcone, niezależne i czynne zawodowo, a już niemal automatycznie - kobiety sukcesu. Nie wszystkie były aktywnymi działaczkami, nie wszystkie same za feministki się uważały. Także określeń: teatr feministyczny/teatr kobiet/kobiecy używano niekonsekwentnie i wymiennie. Ten stan rzeczy nie może dziwić. Jak wykazała Inga Iwasiów, problem $\mathrm{z}$ rozpoznaniem i klasyfikacją gender $\mathrm{w}$ teatrze, a więc i w odnoszącej się do teatru terminologii, utrzymywał się we współczesnej humanistyce bardzo długo. Dopiero, jak się wydaje, dostrzeżenie cech procesualności i performatywności gender w teatrze i dramacie daje nowe możliwości refleksji nad teatrem kobiecym ${ }^{4}$.

W Polsce przełomu lat dwudziestych i trzydziestych, a więc wiele lat po fali ibsenizmu i prapremierach dramatów Zapolskiej, poruszanie problematyki kobiecej w teatrze nie było niczym nowym. Nowe natomiast było to, że dyskurs feministyczny zbiegł się z realnymi i powszechnymi, a nie tylko z postulowanymi, przemianami obyczajowymi, ekonomicznymi i społecznymi, w jakich uczestniczyły kobiety po pierwszej wojnie światowej. W sposób naturalny ich postawy wpisywały się w kontekst pierwszej fali feminizmu w Europie i Stanach Zjednoczonych. Nie trzeba przypominać, że kilkanaście lat po przyznaniu kobietom w Polsce prawa do głosowania (1918) i wpisaniu w 1920 roku do konstytucji Stanów Zjednoczonych 19. poprawki o równości płci, w Polsce międzywojennej rozwi-

3 Zob. M. Morozowicz-Szczepkowska, Z lotu ptaka. Wspomnienia, Warszawa 1968, s. 267.

${ }_{4}^{4}$ Zob. I. Iwasiów, Teatr, dramat, gender - wyznaczniki przestrzeni komunikacyjnej, [w:] Inna scena. Kobiety $w$ historii $i$ wspótczesności teatru polskiego, red. A. Adamiecka-Sitek, D. Buchwald, Warszawa 2006, s. 18-21. Zob. również: W. Baluch, M. Sugiera, J. Zając, Dyskurs, postać i płeć w dramacie, Kraków 2009. 
jał się społeczny ruch kobiet. W 1927 roku powstał, pierwszy po od dawna wydawanym „Bluszczu”, programowo otwarty na debatę tygodnik społeczno-literacki „Kobieta Współczesna” Emilii Grocholskiej i Wandy Pełczyńskiej. Działały aktywnie polskie oddziały Międzynarodowej Federacji Kobiet z Wyższym Wykształceniem i Międzynarodowego Stowarzyszenia Kobiet Pracujących ${ }^{5}$. Znakiem firmowym polskiego feminizmu stała się publicystyka i niezależny styl życia Ireny Krzywickiej, ważną publikacją - zbiór wcześniej drukowanych felietonów Piekło kobiet Boya z 1930 roku.

Teatr brał w tym dyskursie udział i go współtworzył, czego najbardziej dla postronnych widocznym przykładem były sceny bulwarowe, gdzie w warunkach swoistej zmowy społecznej łączącej twórców i publiczność dochodziło, za przyzwoleniem tej ostatniej, do przekraczania granic mieszczańskich norm obyczajowych. To samo dotyczyło licznych scenek rozrywkowych, rewii i kabaretów, gdzie wyznaczano trendy wyzwolonej z konwenansów mody i gdzie obecność kobiet - przy stolikach, na parkiecie i na estradzie, ich niezależność i nieskrępowana seksualność stały się normą. Hanka Ordonówna, Mira Zimińska, tancerki Loda i Zizi Halama i wiele innych artystek przesunęło jej granicę. Z pozycji maskulinistycznej tak widział te trendy Słonimski: „Dziś, gdy kobieta może sama chodzić do kawiarni i do restauracji, różnica między kokotką a damą z towarzystwa bardzo się zatarła. Jest przez to być może większa konkurencja, ale i możliwości są większe. Przybył również bardzo ważny czynnik, a jest nim praca kobiet. Praczka, szwaczka czy nawet nauczycielka nie miały okazji do tańczenia z najwyższymi dygnitarzami państwowymi co może osiągnąć dziś każda ładna i zgrabna biuralistka"6. Nie było to podejście odosobnione.

Mimo podobnych postaw krytyków z coraz większym odzewem spotykała się fala dramatów kobiecych/feministycznych. Stało się to możliwe dzięki teatrowi, który wystawiał je niemal natychmiast, zapewniał wysoki na ogół poziom inscenizacji, a za pośrednictwem polemik prasowych trafiał do licznej rzeszy odbiorców. Doszło przy tym do swoistej „zmowy kobiet" - szeregu wspólnie podejmowanych przez autorki, reżyserki, aktorki, tłumaczki i scenografki działań w celu zamanifestowania w teatrze podobnych poglądów. Istnieniu nieformalnej, jakby powiedział Irzykowski, „ruchliwej” grupy inscenizatorek trudno zaprzeczyć. Niekiedy, jak zrobiła to Jagoda Hernik-Spalińska, w jednej z pierwszych publikacji poświęconych przedwojennemu nurtowi kobiecemu w polskim teatrze, s. 268.

${ }^{5} \mathrm{Z}$ satysfakcją wymienia te zjawiska M. Morozowicz-Szczepkowska, Z lotu ptaka...,

${ }^{6}$ A. Słonimski, Gwałt na Melpomenie, t. 2, Warszawa 1959, s. 22. 
sytuuje się realizacje dramatu kobiecego lat trzydziestych w okolicy niemieckiego Zeittheater ${ }^{7}$ - z racji współczesnej, niejednokrotnie drastycznej, tematyki społecznej. Klasyfikacja słuszna tylko po części i tylko wówczas, gdy pominąć polityczny aspekt Zeittheater, polskim feministkom-inscenizatorkom raczej obcy. Należy natomiast zadać pytanie, czy znalazły one swój własny język, czy ich teatr był rzeczywiście w jakiś sposób odrębny.

To trochę paradoks, że za początek feministycznej fali w polskim teatrze uważa się premierę dramatu napisanego przez mężczyznę - Friedricha Wolfa. Jego Cjankali, sztukę poruszająca temat aborcji, wystawił w styczniu 1930 roku w Teatrze Miejskim w Łodzi, za dyrekcji Karola Adwentowicza, Leon Schiller8. Spektakl wywołał burzliwą dyskusję. Jej zaskakująca jawność, jako ważny czynnik debaty publicznej, stała się w sposób znaczący konstytuująca dla nurtu kobiecego. Już wcześniej można było dostrzec jego zapowiedzi - nie zostały jednak odczytane. W 1922 roku w krakowskiej Bagateli wystawiono dwuosobowy dramat jeden z największych scenicznych przebojów międzywojnia - Świt, dzień i noc Dario Niccodemiego ${ }^{9}$. Utwór dostarczyła Marianowi Dąbrowskiemu, właścicielowi i dyrektorowi tego wzorowanego na paryskich scenach bulwarowych teatru, tłumaczka Zofia Jachimecka. W przedstawieniu debiutowała żona reżysera, scenografka i projektantka mody Zofia Węgierkowa. Zręcznie napisany, psychologiczny dramat był okazją do popisu aktorów - Marii Malickiej i Aleksandra Węgierki10. Poruszaną w tekście kwestię równorzędnego statusu kobiety w relacji uczuciowej z mężczyzną unieważniła konwencja bulwarowego teatru rozrywkowego. $\mathrm{Z}$ pobłażaniem przyjęta też została przez recenzentów krakowska premiera Kochanka Sybilli Thompson Pawlikowskiej-Jasnorzewskiej w 1926 roku - futurystyczna opowiastka o tytułowej bohaterce, która poddaje się zabiegowi odmładzającemu i odrzucając wszelkie normy społeczne, wyjeżdża z (również odmłodzonym) kochankiem na Księżyc ${ }^{11}$.

Dwa miesiące po łódzkiej premierze Cjankali Teatr Polski Arnolda Szyfmana w Warszawie wystawił Dom kobiet Nałkowskiej w reżyserii Marii Przybyłko-Potockiej - o kobietach wartościujących własne życie $\mathrm{z}$ perspektywy męskiej akceptacji ${ }^{12}$. W tym samym roku inny dramat

7 J. Hernik-Spalińska, Rodzaju żeńskiego, „Dialog” 1996, z. 3, s. 150.

8 W przekładzie Bolesława Jana Frühlinga, prapremiera polska 14 I 1930.

9 Prapremiera polska 11 IX 1922.

10 We wrześniu 1923 Malicką i Węgierkę zaangażował do Warszawy Arnold Szyfman. Spektakl Świt, dzień i noc z ich udziałem w Teatrze Małym stał się przebojem i początkiem ich gwiazdorskich karier.

11 Teatr im. J. Słowackiego, reż. J. Chodecki, prapremiera 2 IV 1926.

12 Prapremiera 21 III 1930. 
Nałkowskiej Dzień jego powrotu - o mordercy bezwarunkowo kochanym przez oddaną mu kobietę, przedstawiały w ramach wspólnego tournée po Polsce Irena Solska i Stanisława Wysocka13; w kwietniu 1931 roku Dzień jego powrotu w reżyserii Emila Chaberskiego wystawiony został w Teatrze Narodowym. Późniejszy dramat Nałkowskiej - Niedobra mitość (1936, Teatr Narodowy, reż. Ryszard Ordyński) nie był już sukcesem. Hernik-Spalińska zauważyła, że inscenizacje sztuk Nałkowskiej „to nawet nie początek, to co najwyżej fałszywy alarm”, bo jej utwory „nie miały cechy literatury feministycznej, która analizuje nie kobiety, ale właśnie mężczyzn"14. Jednak rola Nałkowskiej była w pewnym sensie decydująca. To w opozycji do Domu kobiet powstał pierwszy polski sceniczny, feministyczny manifest.

Za taki uznana została - m.in. przez Boya - Sprawa Moniki Morozowicz-Szczepkowskiej wystawiona po raz pierwszy teatrze Reduta w Warszawie 20 lutego 1932 roku. Ukazanie w sposób kameralny i intymny odrębności świata kobiet w opozycji do norm stworzonych przez mężczyzn, otwarta dyskusja na temat kobiecej niezależności i pozycji społecznej, prawa wyboru modelu życia, definiowania kobiecości już nie poprzez poddaną męskiej dominacji cielesność i emocjonalność, lecz poprzez udział w życiu publicznym - nabrało wyraźnych jak nigdy wcześniej kształtów. Prapremiera Sprawy Moniki na kilka lat wyznaczyła kierunek inscenizacji dramatu kobiecego. Nie bez znaczenia był fakt, że spektakl grano w Reducie, teatrze, w którym niemal żadna premiera nie mijała bez echa i który wciąż był w Polsce wzorem kameralnego psychologicznego aktorstwa i dogłębnej interpretacji tekstu dramatycznego. Temperaturę oczekiwania na premierę podnosiła szeptana plotka, że oto gdzieś $\mathrm{w}$ Warszawie, poza oficjalnym planem repertuarowym, w tajemnicy, powstaje ważny, kobiecy, być może skandalizujący, spektakl-manifest.

Morozowicz-Szczepkowska, aktorka i córka aktora, reżysera i dyrektora teatrów Rufina Morozowicza, jako autorka, zarazem reżyserka debiutowała w 1913 roku w Poznaniu sztuką Kabotyni (grała w niej główną rolę). Wystawiono później dwie jej komedie, ale dopiero Sprawa Moniki przyniosła sukces. Małoobsadowy dramat na trzy aktorki i telefon ukazuje w kulminacyjnym momencie losy młodej lekarki - tytułowej Moniki która poddaje się niebezpiecznej operacji nie tyle nawet, by móc zajść w upragnioną ciążę, ile by urodzić dziecko uwielbianemu mężczyźnie, jej przyjaciółki Anny, niezależnej finansowo architektki odnoszącej sukces zawodowy, i służącej Antosi, która prosi Monikę o pomoc w dokonaniu aborcji. O tym, że Antosia nosi dziecko męża Moniki, obie kobiety dowie-

13 Prapremiera w teatrze Bagatela w Krakowie 4 VIII 1930.

14 J. Hernik-Spalińska, Rodzaju żeńskiego, s. 151. 
dzą się w trakcie akcji. Mężczyzna w tym dramacie należy do świata zewnętrznego, pozakobiecego - obecny jest jedynie w rozmowach bohaterek, a fizyczne - jest poza sceną, na drugim końcu linii telefonicznej. To kobiety, relacje pomiędzy nimi i ich osobiste wybory są tematem sztuki. Sama autorka za główny problem ukazany w dramacie uznała „wyrwanie się kobiety z pęt seksualizmu i dojście do pełni człowieczeństwa poprzez pracę"15. Anna wypowiada do zdradzonej przez męża, bliskiej samobójstwa Moniki, często cytowane słowa: „Sprzeniewierzasz kapitał włożony w ciebie, kapitał nauki, pieniędzy, nadziei, jesteś dezerterem z pola walki!... [...] Sprawę ważną i wielką sprzedajesz za uścisk miłosny, mała, licha samiczko!..."16. Trzy kobiety, bohaterki spektaklu, każda przez tego samego mężczyznę zdradzona lub porzucona, na koniec solidaryzują się, każda odnajduje własną drogę w życiu. Anna mówi: „Mam pracę, to mądry, piękny i wierny towarzysz". Monika wraca do świata po osobistej klęsce ze słowami: „Uczę się, chcę się nauczyć”17 - w domyśle: żyć na nowo. Służąca Antosia zapowiada: „To się wydrę, wylezę na wierzch... nie boję się niczego... ciekawość taką mam na wszystko, że na koniec świata bym poszła!"18.

Bodaj po raz pierwszy w polskim teatrze został zrealizowany projekt w całości kobiecy - trochę przez przypadek, a trochę z konieczności ${ }^{19}$. Najpierw Morozowicz-Szczepkowska wysłała dramat Arnoldowi Szyfmanowi i przeczytała go Stefanowi Jaraczowi. Szyfman odpisał zdawkowo: „Sztuka dobra, na spektakl za krótka”, Jaracz stwierdził: „Z pasją napisana. To tylko trzy kobiety. Musi być dobrze grana” i dodał że „Nie ma takich aktorek"20. Wtedy dopiero autorka przekazała tekst Zofii Modrzewskiej, aktorce teatrów Polskiego i Małego, byłej żonie Leona Schillera. „Ja na taką sztukę czekałam, to jest nasza sztuka, sztuka kobiet!”21 - mówi Modrzewska i z Zofią Małynicz, która obejmuje rolę Anny oraz Zofią Mysłakowską w roli Antosi - zaczyna w swoim mieszkaniu próby. Podczas pierwszego spotkania autorka, by nie deprymować koleżanek, ukrywa się w drugim pokoju, dekonspiruje się jednak po chwili i angażuje się we wspólną pracę nad spektaklem. Po kilku tygodniach dołączy do nich Irena Grywińska. To ona zagra Monikę. Tygodniami trwają próby

15 M. Morozowicz-Szczepkowska, Z lotu ptaka..., s. 279.

16 Taż, Sprawa Moniki, Warszawa 1933, s. 61.

17 Tamże, s. 65.

18 Tamże, s. 71.

19 W roku 1903 Gabriela Zapolska zaproponowała odbywającej ostatnie polskie tournée Helenie Modrzejewskiej wspólne wystawienie swego napisanego dla niej dramatu Jesiennym wieczorem, do realizacji jednak nie doszło.

20 M. Morozowicz-Szczepkowska, Z lotu ptaka ..., s. 277.

21 Tamże, s. 279. 
analityczne, z czasem, już w trakcie prób sytuacyjnych, ustawiane są dialogi i całe sceny - w afabularnej kolejności, bo linię rozwojową spektaklu na tym etapie tworzy raczej ich ładunek emocjonalny, a nie miejsce w łańcuchu zdarzeń. Proces prób staje się wartością samą w sobie. Aktorki - zgodnie z Redutową metodą pracy - stopniowo zżywają się z postaciami. Wspominała Morozowicz-Szczepkowska: „Każde zdanie jest szczegółowo opracowywane, wielokrotnie nicowane, gruntownie przemyślane, odpowiednio pod względem głosowym modulowane - a wszystko to odbywa się w ferworze nieustannych, toczonych $\mathrm{z}$ wielką pasją dyskusji, mających na celu jedno: wydobycie najgłębszej treści słowa. [...] Tworzenie żywych postaci scenicznych to ustawiczne dochodzenie, dociekanie, śledzenie wszystkich odruchów człowieka, przenikanie go aż do dna, do samej istoty, to zarazem odczuwanie przejaskrawień i ekshibicjonizmu. [...] Te kobiety nie grały, one naprawdę były"22. Grywińska pisała po latach: „niezwykle żarliwie prowadziłyśmy między sobą, nieraz do późnej nocy, długie dyskusje na temat charakterów odtwarzanych postaci"23. Przygotowania trwały prawie rok. Zdaniem Morozowicz-Szczpkowskiej: „Kilka razy zdawało się, że zespół ten już się rozleci, wykonawczynie bowiem nie wytrzymywały tempa i intensywności pracy reżyserki, która dosłownie poddawała je męczarniom wżywania się w role, przeistaczania fikcji literackiej w żywe postacie"24. Na koniec spektakl został pokazany Juliuszowi Osterwie i grupie przez niego zaproszonych działaczek. Według Grywińskiej Osterwa obiecał „wziąć sztukę pod opiekę” pod warunkiem, że inscenizatorki nad nią jeszcze popracują, Morozowicz-Szczepkowska twierdziła, iż ,sam wprowadził jeszcze pewne retusze, nie uniknąwszy przy tej okazji kilku sprzeczek z Zofią"25. Premiera odbyła się $\mathrm{w}$ niewielkiej salce Reduty, owalnej, bez kurtyny, gdzie aktorki grały w bezpośredniej bliskości z publicznością. Powodzenie przerosło wszelkie oczekiwania. W ciągu roku zagrano spektakl ponad 300 razy, było o nim głośno w całej Polsce. Wkrótce Sprawę Moniki wystawiły inne teatry - od Gdańska po Sosnowiec i od Poznania po Kielce, a miarą sukcesu było przetłumaczenie tekstu na kilka języków, inscenizacje w Niemczech, Jugosławii, Czechosłowacji, a nawet - ale już bez powodzenia - na Broadwayu. Na podstawie sztuki powstał hollywoodzki film Doktor Monika w reżyserii Williama Keighleya - obraz przeciętny, co nie umniejszało sukcesu autorki.

22 Tamże, s. 280.

${ }^{23}$ I. Grywińska-Adwentowicz, Sprawa Moniki, [w:] O zespole Reduty 1919-1939, Warszawa 1970, s. 283.

24 M. Morozowicz-Szczepkowska, Z lotu ptaka..., s. 281.

${ }^{25}$ I. Grywińska-Adewntowicz, Sprawa Moniki, s. 283; M. Morozowicz-Szczepkowska, Z lotu ptaka..., s. 281. 
Morozowicz-Szczepkowska i Modrzewska, która po sukcesie Sprawy Moniki porzuciła aktorstwo i poświęciła się głównie reżyserii, zrealizowały wspólnie jeszcze kilka przedstawień. Inscenizacja Milczacej siły w Reducie we wrześniu 1933 roku, mimo udziału Stanisławy Wysockiej, nie miała już jednak powodzenia. Akcja dzieje się w przyszłości, bohaterką jest - imię nie bez znaczenia - Ewa, przywódczyni dziesięciomilionowej międzynarodowej organizacji kobiecej. Głosi ideę walki przy użyciu instrumentów ekonomicznych, propagandowych i politycznych. Modrzewska znów uwalnia swoją bohaterkę od zależności od mężczyzny, znów pokazanego jako jednostka słaba i mało wartościowa - Ewa odrzuca oświadczyny nieodpowiedzialnego kochanka sprzed lat, ojca jej dorosłego już syna, którego wychowała samotnie. I to syn, przez nią i tylko przez nią ukształtowany, jest jedynym przedstawicielem płci przeciwnej, z jakim Ewa odczuwa więź emocjonalną. Cel swych działań na rzecz kobiet bohaterka ujmuje zdaniem: „to nie jest walka z mężczyzną, to walka o swoje miejsce"26. Sztuka okazała się słaba, pozbawiona dramaturgii, przeładowana tyradami. Irzykowski skwitował premierę: „i ten dramat tak samo jak poprzedni ma typowe wady i typowe zalety literatury feministycznej (o ile ją piszą kobiety): żarliwość i energia w propagandzie, płytkość w ujęciu"27. Następny kobiecy projekt - spektakl Typ A, grany w warszawskim Ateneum (premiera 20 XI 1934), do zrealizowania którego reżyserka Modrzewska i autorka - Morozowicz-Szczepkowska zaprosiły scenografkę Zofię Ruszkowską, wywołał skandal. To po tej premierze Słonimski napisał słynne słowa: „Kobieta napisała, kobieta wyreżyserowała i kobieta zrobiła dekoracje. Wszystko jest rodzaju żeńskiego. Podnosi się ta kurtyna i na tej scenie rozpoczyna się ta akcja tej komedii. Brakuje tylko sensu, bo sens jest rodzaju męskiego, brakuje dowcipu, bo to też rodzaj męski, jest natomiast nuda rodzaju żeńskiego. Streszczenie pierwszego aktu jest niemożliwe. Akt drugi kończy się początkiem aktu (płciowego)"28. Incydentem, który wywołał skrajne reakcje krytyków, było pokazanie po raz pierwszy na polskich scenach nagiego mężczyzny, Władysława Surzyńskiego, w starannie pod względem scenograficznym opracowanej i uzasadnionej dramaturgicznie scenie pozowania do obrazu bohaterce - malarce ${ }^{29}$. Obnażona na scenie cielesność męska stała się pretekstem do negowania wszelkich użytych przez autorkę sensów i na-

${ }^{26}$ M. Morozowicz-Szczepkowska, „Milcząca siła”, maszynopis w zbiorach Archiwum Artystycznego i Biblioteki Teatru im. J. Słowackiego w Krakowie, sygn. 3238, s. 26.

${ }^{27}$ K. Irzykowski, Pisma teatralne..., s. 685.

28 A. Słonimski, Gwatt na Melpomenie, s. 212.

${ }^{29}$ Pierwszą nagą aktorką w polskim teatrze była Irena Solska w tytułowej roli w dramacie Lady Godiwa Jerzego Żuławskiego w roku 1908 w Krakowie. 
raziła ją na niewybredne kpiny: „Autorka chciałaby [...] dać sztuce jakiś sens serio, zmacać jakąś ramę społeczną, ale [...] jeśli się domacała, to absolutnie czego innego" - kpił niewybrednie Boy ${ }^{30}$, a Słonimski stwierdził: „Strona filozoficzna utworu [...] przysłonięta jest tajemniczą i nieprzeniknioną mgłą. Być może, trzeba być kobietą, aby zrozumieć, po co ta sztuka została napisana" 31 . Modrzewska zamierzała odpowiedzieć krytykom, ale jej list opublikowała dopiero po latach Morozowicz-Szczepkowska w swoich wspomnieniach: „obrazili się [...] nie tyle krytycy co mężczyźni. Obrazili się za zlekceważenie swojej płci, nie godności męskiej, ta w sztuce wychodzi bez szwanku, nie poczucia humoru, tradycji człowieczeństwa, lecz, po prostu, zwyczajnie, panującej nam miłościwie płci męskiej! Tabu! Zdaniem tych panów, rzecz to niebywała i niedozwolona, aby kobieta ośmieliła się śmiać z męskości, rozebrać na scenie mężczyznę. Całe wieki rozbierano tylko kobietę, aby ją poklepać, okiem znawcy «towar» obejrzeć i ze śmiechem lub łezką rozczulenia do... alkowy wprowadzić. Ale rozebrać na scenie mężczyznę?! Kobieta rozbierająca mężczyznę?! Tego jeszcze nie było!"32.

W listopadzie 1932 roku, w Teatrze Kameralnym Karola Adwentowicza w Warszawie doszło do premiery głośnego dramatu Dziewczęta $w$ mundurkach niemieckiej autorki Christy Winsloe, granego później m.in. w Krakowie, Łodzi, Poznaniu, Lwowie i innych miastach. Winsloe sztukę, przerobioną z własnej powieści, oparła na swoich wspomnieniach. Po berlińskiej premierze w roku 1931 powstał film pod tytułem Mädchen in Uniform, wyreżyserowany przez uczennicę Maksa Reinhardta Leontine Sagan. Film zdobył rozgłos i wzbudził gwałtowną dyskusję. Winsloe, ze względu na swój homoseksualizm, musiała opuścić coraz bardziej duszną Republikę Weimarską i wyjechała do Francji ${ }^{33}$. Czy Grywińska widziała film Sagan - wątpliwe, bo do Polski trafił dopiero w 1934 roku. Zdobyła natomiast egzemplarz sztuki, przetłumaczyła ją i poprosiła Modrzewską o reżyserię i Zofię Węgierkową o opracowanie scenografii.

Sztuka opowiada o szkole $\mathrm{z}$ internatem dla dobrze urodzonych dziewcząt. Uczennice są poddawane bezwzględnej dyscyplinie. Bohaterką jest piętnastoletnia Manuela, która zakochuje się w jedynej niepozbawionej empatii nauczycielce (Irena Grywińska). Odruchy życzliwości ze strony wychowawczyni wrażliwa dziewczyna odbiera jako dowody przywiązania. Zachęcona pochwałą po występie w szkolnym przedstawieniu Manuela

30 „Kurier Poranny” 1934, nr 325.

31 A. Słonimski, Gwatt na Melpomenie, s. 213.

32 M. Morozowicz-Szczepkowska, Z lotu ptaka..., s. 285.

${ }^{33}$ W 1944 roku Winsloe wraz ze swoją partnerką została zabita z rąk człowieka, który posądził ją o szpiegostwo na rzecz Niemiec. Sprawca został osądzony za to morderstwo. 
wyznaje głośno swoje uczucie, co natychmiast dociera do przełożonej szkoły (Ewa Kunina). Dziewczyna jest szykanowana, a gdy jej ukochana nauczycielka, chcąc ją chronić, odsuwa się, rzuca się z okna. Rolę Manueli zagrała w Kameralnym siedemnastoletnia wówczas Jadwiga Andrzejewska. I to ona sprawiła, że spektakl odniósł ogromny sukces. Zrealizowane $\mathrm{w}$ skromnych warunkach przedstawienie oparte było na realistycznym aktorstwie w stylu Stanisławskiego. Dążenie do osiągnięcia prawdy na scenie było tak silne, że Andrzejewska na każdym przedstawieniu w kulminacyjnym monologu płakała naprawdę ${ }^{34}$. Co ciekawe, recenzenci zgodnie uznali, że sztuka traktuje o modelu wychowania. Wątek homoseksualny nie został odczytany, ale też nie był w spektaklu akcentowany. Jedynie Irzykowski go dostrzegł, zarazem zlekceważył, nazywając „zezem w stronę przewrotnej erotyki”"35. W ciągu dwóch lat Dziewczęta $w$ mundurkach wystawiono w Wilnie, Krakowie, Kaliszu, Płocku, Łodzi, Stanisławowie, Poznaniu, Lwowie. Do bardziej udanych należała wersja krakowska z 1933 roku w Teatrze im. J. Słowackiego w inscenizacji Modrzewskiej ${ }^{36}$, zaproszonej do współpracy przez dyrektora Osterwę. W dniach poprzedzających premierę i bezpośrednio po niej w prasie pojawiły się liczne publikacje odnoszące się do wymowy dramatu. Pod znamiennym tytułem Hallo! Wróg mężczyzny w Krakowie! ukazała się na łamach „Nowego Dziennika” relacja Mojżesza Kanfera z rozmowy z reżyserką. Pozateatralny kontekst narzucał się sam: „Kraków żyje obecnie pod znakiem Gorgonowej - pisał Kanfer - i interesuje się losami kobiety, która sądzona przez mężczyzn walczy o swe życie”. Modrzewska jasno formułowała swoje poglądy: „mężczyzna [...] rządził dotychczas ludzkością wszechwładnie [...] kobieta, która dotychczas milczała, pozwalając, by nawet w jej imieniu przemawiał mężczyzna, wyzwoliła się ostatecznie”. W jej przekonaniu „Emancypacja nie polega bynajmniej na zdobyciu równouprawnienia politycznego, ale na stworzeniu nowej etyki ludzkiej" 37 . Następnego dnia na tych samych łamach reżyserka w artykule Dlaczego wystawiłam „Dziewczęta w mundurkach” poruszyła drażliwy temat wątku lesbijskiego: „Sztuka Christy Winsloe to szlachetny krzyk o prawdę i światło, troskliwie tłumiony przez głupotę i pruderię wychowawców. Czy Manuela jest chora? Czy miłość jej do panny Bernburg jest perwersyjna, lesbijska, nienormalna? O nie. Manuela jest zdrowa, mocna,

${ }^{34} \mathrm{Za}$ informacje o Andrzejewskiej dziękuję Romanowi Włodkowi.

35 M. Morozowicz-Szczepkowska, Z lotu ptaka..., s. 503.

36 Przekład Grywińska-Adwentowiczowa, oprawa dekoracyjna Mieczysław Różański, premiera 11 III 1933.

37 M.K. [Mojżesz Kanfer], Hallo! Wróg mężczyzny w Krakowie! Rozmowa z p. Zofia Modrzewska, „Nowy Dziennik” 1933, nr 70. 
czysta i piękna - Manuela, mała poetka, zakochała się w pannie Bernburg, a panna Bernburg kocha ją wzajemnie - to wszystko"38. Próbą powtórzenia sukcesu Dziewcząt w mundurkach było wystawienie w roku 1936 w Teatrze Kameralnym Matury Laszlo Fodora w reżyserii Grywińskiej, ponownie z Andrzejewską w roli głównej. Jeszcze raz pokazano środowisko szkolne, poruszono problematykę wychowania i młodzieńczej erotyki. Przy okazji tej dość konwencjonalnej sztuki okazało się, jak dalece męskie spojrzenie recenzentów decydowało o ocenach spektaklu. $\mathrm{Na}$ podstawie sceny, w której bohaterka zjawia się w stroju gimnastycznym w gabinecie dyrektora, Boy i Słonimski zarzucili Grywińskiej błąd obsadowy, uznając Andrzejewską za mało atrakcyjną. Słonimski uważał, że Katarzynę powinna zagrać „wspaniale rozwinięta młoda kobieta, wybuchająca z mundurka szkolnego wszystkim, co kobietę od mężczyzny odróżnia”39, a Boy nazwał obsadzenie głównej roli „cielesnym nieporozumieniem"40.

Dyskusje i polemiki wokół inscenizacji feministycznych szybko zaczęły wykraczać poza prasowe opinie krytyków. W Krakowie po prapremierze Egipskiej pszenicy Pawlikowskiej-Jasnorzewskiej (1932, reż. Józef Karbowski) z Zofią Jaroszewską w roli głównej, debata toczyła się nie tylko na łamach prasy, ale też podczas spotkań z publicznością w salach Kolegium Wykładów Naukowych i sali Kopernikańskiej w Collegium Novum - z licznym udziałem studentów uniwersytetu. Leon Templer wprost pisał o kwestiach „odrębności natury kobiecej” i „pełnego prawa kobiety do odrębnego życia" 41 . Krytyków i publiczność poruszała przedstawiona w Egipskiej pszenicy historia bohaterki o imieniu Ruta, oskarżanej przez męża i jego matkę o niezdolność do macierzyństwa. Po wielu perypetiach i upływie lat Ruta dojrzewa do niezależności, zakochuje się z wzajemnością, rodzi syna młodemu kochankowi i nie kryje tego przed światem. „Ruta Krzeptowska [...] już nie woła, lecz po prostu stwierdza swe prawo do kierowania swym życiem na równi z mężczyzną, więcej, bo zgodnie $\mathrm{z}$ wymaganiami i potrzebami własnej natury kobiecej, odrębnej od natury męskiej, lecz tak samo człowieczej. Śmiałe i jasne postawienie tego zagadnienia, z wyciągnięciem stąd krańcowych konsekwencyj, było możliwe dopiero dziś, gdy kobieta, zrzuciwszy z siebie krępujące ją więzy

38 Z. Modrzewska, Dlaczego wystawiłam „Dziewczęta w mundurkach”, „Nowy Dziennik” 1933, nr 71. Sześć lat wcześniej, w roku 1927 w Krakowie po wystawieniu poświęconej miłości lesbijskiej sztuki Édouarda Bourdeta $W$ pętach w przekładzie Boya (premiera 8 X 1927), wybuchł skandal.

39 A. Słonimski, Gwatt na Melpomenie, s. 283.

40 T. Żeleński-Boy, Perfumy i krew. Krótkie spięcia, Warszawa 1969, s. 343.

${ }^{41}$ L. Templer, Zwrot $w$ twórczości Marii Pawlikowskiej. Na marginesie premiery „Egipskiej pszenicy”, „Nowy Dziennik” 1932, nr 277. 
konwenansów i innych przeżytków obyczajowych czy społecznych, sama we własnym przemawia imieniu" - przedstawiał ideę dramatu Kazimierz Czachowski w odczycie wygłoszonym w Kolegium Wykładów Naukowych $^{42}$. „W wyzwoleniu się kobiety spod przytłaczającego ją kompleksu spraw męskich, w tym jej uczłowieczeniu się, które stało się faktem dopiero $\mathrm{w}$ naszej dobie powojennej i jako jeden $\mathrm{z}$ wyników przemian społecznych, wywołanych przez wojnę, w tym dojściu kobiety do dojrzałości własnej kobiecej dopatrywać się można istotnych przyczyn owego dającego się zauważyć najazdu kobiet na literaturę"43 - dodawał. Egipska pszenica wywołała entuzjazm młodych literatów (m.in. Wiesława Goreckiego) i niechęć konserwatywnych krytyków. Próbowała polemizować z nimi autorka. Sukces krakowskiej inscenizacji był jednak niekwestionowany, a dramat doczekał się realizacji w innych miastach, m.in. w Łodzi, Lwowie, Warszawie, Katowicach.

Wypowiedzi Czachowskiego należały do wyjątków. Zwykle przeważał lekceważący ton krytyków, nisko na ogół oceniających literacką wartość dramatów feministycznych i lekceważących ich wymowę. Odnosząc się do Dnia jego powrotu Zofii Nałkowskiej - tak parodiował je Irzykowski: „ten z tamta - a jednak i z tą, ta z owym, lecz jeszcze i z innym, a ona płakała, a ona mu się oddała, a on się nie chciał żenić, a ona nim pogardza, a ona go jeszcze pamięta, a on do niej wrócił i tak dalej, te rozmaite kombinacje, te komeraże, to całe sentymentalne cipcilipci - może i powinno się podobać szerokiej rzeszy kobiecej" 44 . Autorki i reżyserki, dążąc przede wszystkim do formułowania problematyki w sposób modelowy, rzeczywiście czerpały garściami z konwencji mieszczańskiego dramatu obyczajowego i teatru bulwarowego, ograniczając formalne eksperymenty do minimum. Dążąc do prawdy psychologicznej, chętnie uciekały się do mocno uproszczonej, freudowskiej psychoanalizy. Po krakowskiej prapremierze Btędnego koła Krystyny autorstwa Modrzewskiej, w jej reżyserii, z Jaroszewską w głównej roli (w 1933 roku), powściągliwi w ocenach recenzenci odrzucili psychoanalityczny koncept zawarty w utworze. Jego bohaterką była porzucona przez męża lekarka, odbywająca we śnie podróż w głąb podświadomości. Modrzewska na łamach „Ilustrowanego Kuriera Codziennego" ogłosiła, że nie jest ani wrogiem mężczyzn, ani zwalczającą ich „feministką”. W jej przekonaniu równy status kobiet i mężczyzn stał się faktem: „Ja nie mogę się dopatrzeć linii okopów, gdzie walczą kobiety

${ }^{42}$ K. Czachowski, O „Egipskiej pszenicy”. Przed premierq teatralna. Z odczytu o Marii Pawlikowskiej-Jasnorzewskiej, wygłoszonego 8-go b.m. w Kolegium Wykładów Naukowych, „Czas” 1932, nr 230; „Ilustrowany Kurier Codzienny” 1932, nr 279.

43 Tamże.

${ }^{44}$ K. Irzykowski, Pisma teatralne..., s. 285. 
z mężczyznami. [...] To nie walka kobiety z mężczyzną, to raczej pomoc dla niego, to raczej walka inżyniera $\mathrm{z}$ inżynierem, doktora $\mathrm{z}$ doktorem, robotnika z robotnikiem, bez względu na płeć. [...] Jesteśmy lekarkami, adwokatkami, sędziami, inżynierami, zasiadamy w sejmie, parlamencie, mamy przedstawicielki w Lidze Narodów, a mimo to ciągle się mówi o kwestii kobiecej. [...] Sztuka moja nie służy partii feministycznej. [...] Sztuka moja to jakby kąpiel w podświadomości..."45. Częstym chwytem było stosowanie dawno sprawdzonej, ibsenowskiej techniki retrospekcji i odkrywania wypartej prawdy. Ulubioną metodą - zmienność planów czasowych i perspektywy spojrzenia - przedstawianie wydarzeń „po latach”, przenoszenie ich w rzeczywistość futurystyczną. Pawlikowska-Jasnorzewska niekiedy posługiwała się rozwiązaniami z gatunku dystopii - w łagodnej wersji w Kochanku Sybilli Thompson oraz w ostrych w wymowie Mrówkach i Babie Dziwo - dramatach odczytanych przez teatr. Wacław Radulski, reżyser krakowskich prapremier Mrówek i Baby Dziwo ${ }^{46}$, przełożył je na język groteski i satyry, podkreślając przy tym kontekst polityczny nasilających się totalitaryzmów.

W ostatecznym rozrachunku najbardziej nośna okazywała się aktualność problematyki, ukazywanie kobiet współczesnych i ich środowiska, silnie realistyczna konwencja gry ${ }^{47}$. O znaczącym oddźwięku teatru kobiecego lat trzydziestych $\mathrm{w}$ ogromnym stopniu decydowała reportażowa proweniencja dramatów. Ten akurat aspekt spotykał się z uznaniem. Według Irzykowskiego to reportażowa forma sprawia, iż publiczność „wierzy autorowi czy autorce na słowo"48.

Reportaż sceniczny rodem z kronik kryminalnych był formą bliską młodej, dwudziestokilkuletniej dramatopisarce Marcelinie Grabowskiej. Szczególnie mocny wydźwięk miał wywiedziony z obserwacji autorki dramat pod ironicznym, celowo ujętym w cudzysłów tytułem „Sprawiedliwość” wystawiony w 1934 roku w Wilnie w reżyserii Mieczysława Szpakiewicza, potem w warszawskim Kameralnym i w Krakowie - tu pod tytułem Kobieta $n r 14^{49}$ i ze zmienionym zakończeniem, co miało złanr 284.

45 Z. Modrzewska, Problemy mojej sztuki, „Ilustrowany Kurier Codzienny” 1933,

46 Prapremiera Mrówek ze scenografią Karola Frycza odbyła się 10 XI 1936 roku, Baby Dziwo ze scenografią Tadeusza Orłowicza - 13 XII 1938.

${ }^{47}$ Fundamentalne znaczenie realizmu w teatrze feministycznym opisane zostało dopiero pod koniec lat siedemdziesiątych XX wieku przez Janet Brown w: Feminist Drama: definition \& critical analysis, Michigan 1979.

${ }^{48}$ K. Irzykowski, Pisma teatralne..., s. 503.

49 Wilno, Teatr na Pohulance - premiera 15 IX 1934, Warszawa, Teatr Kameralny 21 VI 1935; Kraków, Teatr im. J. Słowackiego - premiera 14 II 1937. 
godzić wydźwięk sztuki50. Była to sugestywnie, realistycznie ukazana historia młodej kobiety skazanej za dzieciobójstwo (wysoko oceniona, powściągliwa w środkach rola Teresy Sucheckiej), uwiedzionej podczas odbywania kary przez syna naczelnika więzienia, zmuszonej następnie do aborcji. Stanisław Witold Balicki, porównując sztukę do publicystyki Krzywickiej, z uznaniem podkreślał „obiektywizm reportażu” zastosowany przez Grabowską ${ }^{51}$. Po premierze recenzent nacjonalistycznego „Głosu Narodu” stwierdził nie bez dystansu, że autorka staje „w obronie swej płci"52, a w jej postawie widoczne są „zarysy sympatii do feminizmu” 53 stwierdzenie łagodne, zważywszy, że ze sceny padały słowa jednoznaczne i nie budzące wątpliwości: „Dziecko zabiłam” - brzmiała jedna z kwestii. „A co miałam zrobić? Bo niektóry ma pieniądze, to zabije płód, a ja nie miałam i łatwiej mi było zabić dziecko. [...] A podrzucić? Na mękę i poniewierkę? [...] A on co? Zrobić - to potrafił, ale żeby się zatroszczył!"54. Czołowi krakowscy recenzenci przyjęli programową wymowę spektaklu z konsternacją. Tadeusz Sinko nazwał sztukę „nieprzyjemną”55, zapominając, że to efekt zamierzony. Otwartość wypowiadania poglądów była wspólna dla wszystkich autorek teatru kobiecego. Do ich strategii należało zamieszczanie $\mathrm{w}$ tekstach dobitnie brzmiących ze sceny wypowiedzi o charakterze feministycznych manifestów, haseł i deklaracji. „Och, gdyby ta masa [kobiet] ożyła, gdyby się wypowiedziała [...]! Taki dopływ energii kobiecej, jak transfuzja krwi odświeżyłby anemiczny i wyczerpany organizm świata" - głosiła bohaterka Milczacej siły.

Teatr feministyczny z początku lat trzydziestych okazał się zjawiskiem zauważonym i szeroko dyskutowanym, lecz efemerycznym. Niewątpliwie jednak przez kilka lat w teatrze polskim istniała „ruchliwa grupa” kobiet dobitnie i konsekwentnie artykułujących problematykę kobiecą. Należały do nich dramatopisarki - Nałkowska, Morozowicz-Szczepkowska, Modrzewska, Grabowska, Gojawiczyńska, z zagranicznych Winsloe, aktorki - Grywińska, Małynicz, Mysłakowska, Jaroszewska,

50 Pisałam na ten temat obszerniej w artykule Wróg mężczyzny w Krakowie. Polska dramaturgia kobieca $w$ teatrze krakowskim okresu międzywojennego, [w:] Inna scena..., s. $62-63$.

51 (s.w.bal.) [Stanisław Witold Balicki], 120 wierszy o teatrze krakowskim, „Tempo Dnia” 16 II 1937.

52 Mcd, „Ilustrowany Kurier Codzienny” 1937, nr 48.

53 A. Waśkowski, Z Teatru im. Stowackiego. Kobieta nr 14 - sztuka Marceliny Grabowskiej, „Głos Narodu” 1937, nr 47.

${ }_{54}$ M. Grabowska, „Kobieta nr 14 (Sprawiedliwość)”, maszynopis, Archiwum Artystyczne i Biblioteka Teatru im. J. Słowackiego w Krakowie, sygn. 453, s. 5.

55 T.S. [Tadeusz Sinko], Romans $w$ kryminale, „Czas” 1937, nr 48. 
Solska, Wysocka i wiele innych, scenografki - Węgierkowa, Ruszkowska, recenzentki i publicystki, wreszcie reżyserki, spośród których najbardziej z nurtem utożsamiana była Modrzewska. A przecież nie wolno zapominać i o tych raczej rzadko wypowiadających się w kwestiach feministycznych kobietach w różnym wieku i o rozmaitych artystycznych i życiowych doświadczeniach, które w znaczący sposób decydowały o kształcie życia teatralnego. Własne lub repertuarowe teatry prowadziły Stanisława Wysocka, Irena Solska, Nuna Młodziejowska, Maria Malicka, Halina Starska, uznanymi reżyserkami były Wysocka, Maria Dulęba, Stanisława Perzanowska, Maria Przybyłko-Potocka... Czy istniała swoista zmowa kobiet w teatrze międzywojennym? Irzykowski po premierze Dziewcząt $w$ mundurkach wzdychał: „Niewiasta kochała niewiastę, niewiasta przeszkodziła, niewiasta napisała, niewiasta przełożyła, niewiasta reżyserowała, niewiasta deklamowała, same niewiasty grały - nie masz mężczyzn w naszej chacie"56. Przesadzał, bo do zmowy kobiet z pewnością trzeba by zaliczyć przynajmniej kilku mężczyzn je wspierających - Juliusza Osterwę, Karola Adwentowicza, Zygmunta Nowakowskiego, Karola Frycza, Arnolda Szyfmana - bo to oni kierowali teatrami, w których realizowano feministyczne inscenizacje, a także Ryszarda Ordyńskiego, Aleksandra Węgierkę, Józefa Karbowskiego, Jerzego Chodeckiego, Wacława Radulskiego i innych mężczyzn reżyserujących dramaty o tematyce kobiecej.

\section{BIBLIOGRAFIA}

Baluch W., Sugiera M., Zając J., Dyskurs, postać i płeć w dramacie, Kraków 2009.

Brown J., Feminist Drama: definition \& critical analysis, Michigan 1979.

Hernik-Spalińska J., Rodzaju żeńskiego, „Dialog” 1996, z. 3.

Inna scena. Kobiety $w$ historii $i$ wspótczesności teatru polskiego, red. A. Adamiecka-

-Sitek, D. Buchwald, Warszawa 2006.

Irzykowski K., Pisma teatralne 1930-1933, t. 3, Kraków 1995.

Morozowicz-Szczepkowska M., Sprawa Moniki, Warszawa 1933.

Morozowicz-Szczepkowska M., Z lotu ptaka. Wspomnienia, Warszawa 1968.

O zespole Reduty 1919-1939. Wspomnienia, Warszawa 1970.

Poskuta-Włodek D., Dzieje teatru $w$ Krakowie w latach 1918-1939. Zawodowe teatry dramatyczne, Kraków 2012.

Słonimski A., Gwałt na Melpomenie, t. 2, Warszawa 1959.

Żeleński-Boy T., Perfumy i krew. Krótkie spięcia, Warszawa 1969.

${ }^{56}$ K. Irzykowski, Pisma teatralne..., s. 505. 
Archiwalia, w tym maszynopisy autorskie i egzemplarze teatralne dramatów Marceliny Grabowskiej, Marii Morozowicz-Szczepkowskiej, Zofii Modrzewskiej, Marii Pawlikowskiej-Jasnorzewskiej i in., Archiwum Artystyczne i Biblioteka Teatru im. J. Słowackiego w Krakowie

Archiwum Narodowe w Krakowie, akta TM

\section{PRASA}

„Czas” 1932, nr 230; 1937, nr 48

„Dialog” 1996, z. 3

„Głos Narodu” 1937, nr 47

„Ilustrowany Kurier Codzienny” 1932, nr 279; 1933, nr 284; 1937, nr 48

„Nowy Dziennik” 1932, nr 277; 1933, nr 70, nr 71 